\title{
USING AUTHENTIC MATERIAL TO IMPROVE THE STUDENTS' LISTENING SKILL
}

\author{
Yasser Mallapiang \\ English Education Department, Faculty of Teacher Training and Education \\ Muhammadiyah University of Makassar \\ yasser.mallapiang@unismuh.ac.id.
}

\begin{abstract}
The research is aimed to find out the Authentic Materials improve the students' listening comprehension in terms of inferred meaning comprehension at the Second Year Students' of SMP Negeri 4 Makassar. This research was an Experimental Research. This research was conducted at SMP Negeri 4 Makassar. The subject of the research is class VIII.A in academic year of 2014-2015 which consists of 30 students, involved of 16 men and 14 women who was taken as the responders of the research. The instrument of this research is listening test namely fill the blank test. The finding of this research shows the mean score of students on pre-test in utterance was 3.13. This was categorized as poor category and after post-test was 6.3 become fair. The mean score on pre-test in conclusion was 3, 53. This was categorized as very poor and after post-test were 6.8 become fairly good. The use of authentic materials is one of a good technique in teaching listening Skill. The data indicates that this technique had succeeded to improve the students' listning skill in terms of inferred meaning comprehension at the Second Year Students' in SMP Negeri 4 Makassar.
\end{abstract}

Keywords: authentic materials, listening, inferred meaning

\section{INTRODUCTION}

Listening plays a significant role in the lives of people. Of the four major areas of communication skills and language development listening, speaking, reading, and writing.

Teaching listening is one of the duties that have to be conducted by teacher of English to improve the students' listening ability in English. In many traditional language courses, listening is neglected. Great emphasis is put on memorizing grammar rules. A great deal of reading is done. In communicative classes, speech is also emphasized. But for some strange reason, listening is rarely stressed (Hoge,2006:1).

English is taught from the elementary school to the university. The main purpose of the subject is to make the students able to communicate and express their ideas in English but for knowing it all, the students have to know more about vocabularies and more extensive reading to make them easy in reading English 
text book and write information in English. The students used language in order to communicate to one another, to express their personal reaction to situation.

Listening skill is one of the important skills of four language learning skills. On the other hand, it is estimated that nearly 90 percent of the class time in high school and university is spent in listening to discussion and lectures. Oxford Dictionary defines it as make an effort to hear something: listen to the radio; listening for the bell. Krashen (1980), states in his input hypothesis, that the role of listening for acquisition is undeniable. It is importance role, it is a so-called Cinderella skill. Nunan, (1997: 47) in EFL situation, receiving only slight emphasis in instruction. Schmitt (2002:193) said that traditionally listening was considered as a passive process, in which our ears were receivers into which information was poured.

In teaching listening comprehension or the other language skills, one of the most factors which should be paid attention by teachers is the materials. One way to prepare ESL students for encounters with real language is to apply real language or authentic speech in the ESL. Therefore, many English teachers or facilitators seeking the innovative and trends for teaching and developing a skill of the students. One of them is using an authentic material in teaching English in the classroom. Used the term authentic to refer to language samples, that reflect a naturalness of form, and an appropriateness of cultural and situational context that would be found in the language as used by the native speakers as a teacher, it is important to find out some methods to solve the problems that faced by the students. One way to attract the students' attention in learning English especially for listening is using whispering games. The use of whispering game as a strategy in teaching listening helps the students to be an active listener. Active listening make the students listen with an active mind so that they can understand and know about the meaning. The use of whispering game in the classroom make the students interested and enjoyed in learning language because the students have to change to be a prompter and each group works hard become the winner. When learning is fun, they can remember what they have learned. 


\section{CONCEPT OF AUTHENTIC MATERIALS}

\section{Definition of Authentic Materials}

Rogers and Medley (1988: 468), states that the term authentic to refer to language samples that reflect a naturalness of form, and an appropriateness of cultural and situational context that would be found in the language as used by the native speakers, orally. Authentic materials refer to audio/video recordings of a discourse or a conversation that is spontaneously generated by native speakers of the language.

Rogers and Medley (1988:467), state that authentic language refers to written or spoken language which is created by and for a native speaker of the language in which it is produced.

If students are to use the language to communicate effectively in the real world, Rogers and Medley (1988:476) state that students have to experience the language as it is used for real communication among native speakers. This can be done through the use of aural authentic materials in the language classroom. Furthermore, Gilman and Moody (1984:331) state that the teacher should use authentic materials in implementing listening comprehension training at advanced level and with students at the beginning and intermediate levels.

Jordan (1997: 113) states that to authentic texts are not written for the aim of language teaching. Martinez (2002: 1) states that "Authentic would be material designed for native speakers of English used in the classroom in a way similar to the one it was designed for.

Wallace (1992:145) states that authentic texts have been defined as reallife texts, not written for pedagogic purposes. They are therefore written for native speakers and contain real language. Little et al. (1988, as cited in Guariento \& Morley,(2001: 347) state that define authentic material as an authentic text created to fulfill some social purpose in the language community in which it was produced.

The teacher must bring massive amounts of authentic materials into the classroom and make them consistently accessible to the students' .Even though 
the use of authentic texts is necessary, it does not mean that the teacher should abandon the use of materials created for instructional purposes.

Authentic materials can still be useful in another way; empirical studies have confirmed that less proficient students can benefit from such materials. In an investigation of high school students studying German as a Foreign Language, Bernhardt and Berkemeyer (1988:86) state that all levels of students have the capacity to manage using authentic texts. Maxim (2002: 29) state that, the students' limited linguistic competence did not short-circuit their ability to read authentic texts in class with the support of their classmates and instructor.

So that the teacher must bring massive amounts of authentic materials into the classroom and make them consistently accessible to the students'. Even though the use of authentic texts is necessary, it does not mean that the teacher should abandon the use of materials created for instructional purposes.

\section{The Role of Authentic Materials}

There is growing body of research on the role authentic materials on FL teaching. Researchers and teachers increasingly acknowledged the need for and usefulness of authentic materials in the field of language teaching. Empirical studies have substantiated the positive results taken by learners who have opportunities to interact with and deal with authentic texts.

Studies, such as Miller (2005:3) and Thanajaro (2000:78), state that incorporating authentic materials lead to aural language development. In addition, Otte (2006 cited in Al-Musallam, 2009) state that investigated the impact of aural authentic texts on listening comprehension abilities of four adult ESL students at an American university. He concluded that exposure to authentic materials would lead to improving students' listening comprehension abilities and motivation. By the same token, conducting on intermediate-level students, Herron \& Seay (1991:487) state that those students who listened to authentic radio tapes as a substitute for regular classroom activities demonstrated significantly greater listening comprehension than those students for whom the authentic radio program was not a part of the semester's curriculum. Their research confirmed 
that, the more exposure to authentic speech the more improve in listeningcomprehension skill.

Berardo (2006:60), states that the sources of authentic materials that can be used in the classroom are infinite, but the most common are newspapers, magazines, TV programs, movies, songs and literature. One of the most useful is the Internet. Whereas newspapers and any other printed material date very quickly, the Internet is continuously updated, more visually stimulating as well as being interactive, therefore promoting a more active approach to reading rather than a passive one. From a more practical point of view, the Internet is a modern day reality, most students use it and for teachers, there is easier access to endless amounts of many different types of material. From a even more practical/economical point of view, trying to obtain authentic materials abroad can be very expensive, an English paper/magazine can cost up to 3-4 times the price that it usually is and sometimes is not very good. Often by having unlimited access in the work place, looking for materials costs nothing, only time. Authentic materials should be the kind of material that students will need and want to be able to read when travelling, studying abroad, or using the language in other contexts outside the classroom. Authentic materials enable learners to interact with the real language and content rather than the form. Learners feel that they are learning a target language as it is used outside the classroom.

\section{The Steps of Applying Authentic Materials in the Class.}

Time in class is limited. Teachers' teaching is just one of the learning resources for the students. Teachers should raise students' cultural awareness, and encourage them to learn the target culture by themselves. The following is the suggested procedure:

1. The teacher prepares some groups and divides the whole class into four groups.

2. The teacher provides four topics for each group. (The students are allowed to find their own topics if they like). Then they are expected to search as much information as possible on the selected topic. After this, 
they should hold a discussion with their group members on the found information and decide how and who gives the report.

3. On the "report day", the four representatives give their reports one by one. Instead of reading the report, they are asked to retell what they have prepared. The rest of the students should regard this class as a listening practice and respond to it after the report.

4. When the reporter finishes, The students can ask whatever questions related to the report. If the reporter cannot give the answers, he/she can turn to his/her group members.

The students may benefit in two ways if they carry on this plan. First, in the report section, students in fact make a listening class by themselves. Every student is getting involved in this process, so they are highly motivated and willing to listen to each other very carefully. Second, in the preparing process, students may read quite an amount of cultural information, and deal with various authentic materials. Their knowledge on culture is enriched. Day by day, when they come back in the listening classroom, they may find that the authentic listening materials are no longer so difficult, and when they go outside the classroom, they may find it easier to communicate with native speakers.

\section{METHODOLOGY}

The apply design in this research was pre-experimental design as one group pre-test - post-test, it consisted of single class. In this research, the teacher used purposive sampling in which the researcher had chosen the eighth one class (VIII.1) as sample for doing research. The number of sample is 30 students consisted of 16 male and 14 female as the respondent in this research. In this research, the teacher used one kind of instrument, namely an authentic listening test to make the students easy to comprehend the message from the speaker. The research instrument consisted of 10 Items which arranged in fill the blank tests. The test was given twice namely pre-test and post-test. Pre-test was intended to find out the students' comprehension in listening. Post-test was intended to find out the students' development after joining treatment. The research instrument 
between pre-test and post-test are same but different song, the researcher used fill the blank test to know the students' listening comprehension in pretest and used fill the blank test to know the students' listening comprehension in post- test. The procedures of collecting data were the students gave a pre-test to measure the students' listening comprehension, the result of pre-test was compared with the result of post-test after doing treatment, and after doing the treatment, the students was given post-test through listening test in form of multiple choices to assess the students' comprehension. Its result to find out the students' development and their progress. The test wasconducted with the same activities in pre-test.

\section{FINDINGS}

The Students' listening comprehension in Pre- test

1. The following table shows the students' mean score in pre-test

Table 2: The Students' Mean Score in Pre- test

\begin{tabular}{|c|c|}
\hline inferred meaning comprehension & Pre- test \\
\hline Utterance & 3,13 \\
\hline Conclusion & 3,53 \\
\hline
\end{tabular}

The percentage of the students' mean score in Utterance is 3,13 in pre-test which is classified as poor, and then the score in Conclusion is 3.53 in pre-test which is classified as poor. To Classify the score of the students' answers in pretest was 1 student had got scores 7.6-8.5 is classified as good (3.33\%), 4 students had got scores 5.6-6.5 is classified as fair (13.3\%), 10 students had got scores $3.6-5.5$ is classified as poor (33.3\%), 15 students had got scores $0-3.5$ is classified as very poor $(50 \%)$.

2. The following table shows the students' mean score in pre-test Table 3: The Students' Mean Score in Post- test

\begin{tabular}{|c|c|}
\hline inferred meaning comprehension & Post-test \\
\hline Utterance & 6.3 \\
\hline Conclusion & 6.8 \\
\hline
\end{tabular}


The table above showed that the students' mean score in post -test is 6.3 in post-test which is classified as fairly good and then 6,8 in post-test which is classified as fairly good. To Classify the score of the students' answers in postest was 2 student had got scores 9.6-10 is classified as excellent (6.7\%), 7 students had got scores 8.6-9.5 is classified as good (23.3\%), 15 students had got scores $6.6-7.5$ is classified as fairly good (50\%), 6 students had got scores $3.6-5.5$ is classified as poor $(20 \%)$.

3. The development of the Students' means score after giving the treatment. Table 4:The Students' Mean Score in Pre- test and Post test after giving the treatment

\begin{tabular}{|c|c|c|}
\hline inferred meaning comprehension & Pre- test & Post test \\
\hline Utterance & 3,13 & 6.3 \\
\hline Conclusion & 3,53 & 6.8 \\
\hline
\end{tabular}

The table above showed that the students' mean score in Utterance is 3, 13 in pre-test which is classified as poor, in contrary the students' mean score in post -test is 6.3 in post-test which is classified as fairly good and then the score in Conclusion is 3.53 in pre-test which is classified as poor become 6,8 in post-test which is classified as fairly good,. It means that the students' mean score in listening comprehension improved from the Pretest to the Posttest. It indicated that the use of authentic materials was effective to improve the students' listening skill. They were shown in the chart, below:

4. Test of significant difference (value of t-test)

In order to know that whether or not the difference between pretest and posttest are significantly different, the t-test statistical analysis for nonindependent sample was applied. The following table shows the result of the t-test.

\begin{tabular}{|c|c|c|}
\hline Variable & T-test value & T-table value \\
\hline $\mathrm{X} 1=\mathrm{X} 2$ & 10.6 & 1.699 \\
\hline
\end{tabular}


Table above shows that the t-test value (10.6) was greater than the t-table value (1.699). It means that the Null Hypothesis (Ho) is rejected and the alternative hypothesis (H1) is accepted.

From the analysis above, the researcher concludes that there is the significant improvement between before and after giving treatment by using authentic materials in teaching listening. In other word, teaching listening through authentic materials can increase the students listening comprehension.

\section{Hypothesis Testing}

If the t-test value was higher than t-table at the level of significance 0.05 and degrees of freedom (df) $29(\mathrm{~N}-1=30-1)$, thus the alternative hypothesis (HI) would be accepted and Null hypothesis (HO) would be rejected. In contrary, if the value was lower than t-table at the level of significance 0.05 and the degrees of freedom 29 , thus the alternative hypothesis would be rejected and Null hypothesis would be accepted.

\section{CONCLUSIONS}

It was supported by the mean score of students on pre-test in utterance was 3.13. This was categorized as poor category and after post-test was 6.3 become fair. The mean score on pre-test in conclusion was 3, 53. This was categorized as very poor and after post-test were 6.8 become fairly good. As the result of the study reveals that the use of authentic materials had been effective way to improve the students' listening skill, the researcher suggests the following things: It is suggested to the English teacher to use authentic materials as one of materials in the teaching and learning process especially in teaching listening skill.; It is suggested to the English teacher to use the interesting environmental to teach writing to the students; and the teacher should invite and raise the students' interest and motivation in learning by manipulating various ways in presenting productive skill, include listening skill. 


\section{REFERENCES}

Bacon, S.M.1989.Listening for Real in the Foreign-Language Classroom .Foreign Language Annnals, 22, 543-551

1992.Phases of Listening to Authentic Input in Spanish: A Descriptive Study. Foreign Language Annals, 25,317-317.

..S.M., \& Finneman, M.F.1990.A Study of the Attitudes, Motives, and Strategies of University Foreign Language Students and Their Disposition to Authentic Oral and Written Input. The Modern Language Journal, $74,459-473$.

Berardo, S.2006. The Use of Authentic Materials in Teaching of Reading,. The Reading Matrix, 6 (2), 60-69.

Bozorgian. (2003). Enhancing Foreign Language Learning through Listening Strategies Delivered in L1: An Experimental Study. International Journal of Instruction January 2013 vol.6, no.1

Brown,J.,\&Eskenazi,M.2004. Retrieval of Authentic Documents for ReaderSpecific Lexical Practice. In Proceedings of InSTIL/ICALL Symposium, Venice Italy.

Changing minds. Com.2002.Tipes of Listening. Akses Pada Tanggal 2 Maret 2011.Http://Changingminds.Org/Techniques/Listening/Types_Listening.t। Dalle, Basri.2010.Fundamentals of Research Methodology. Makassar.

Depdikbud.1994 Petunjuk Teknik Pengajaran Bahasa Inggris. Jakarta: Depdikbud

Duquete,G.,Dunnet,S.,\&Papalia,A.1989.The Effect of Authentic Materials in Acquiring a Second Language .Canadian Modern Language Review,43,474-492.

D.Tamo. (2009). The Use of Authentic Materials in Classrooms. International Journal Article 9 in LCPJ.

Gunningsworth, Alan.1984.Evaluating and Selecting EFL Teaching Materials. London

Gilman and Moody (1984:331). What Practitioners Say About Listening: Research Implications for the Classroom 
Gordon. (1985:13). an Analysis on How to Improve Tertiary EFL Students' Listening Skill of English

Hewit and Dakin. (1997:3). A Study of English Listening Strategies Applied by Technological University Students

Herron,C.A.,\& Seay ,I.1991.The Effect of Authentic Oral Texts Student Listening Comprehension in the Foreign Language Classroom. Foreign Language

Hoge. 2006: 1. The Vital importance of Listening

Hui-Fang. (2008). Listening Strategy Use and Linguistic Patterns in Listening Comprehension EFL Learners. The International Journal of Listening.

Jordan. The Internet TESL Journal "Authentic Materials and Cultural Content in EFL Classrooms". (1997:113).

Karakas. (2002). Journal of Language Teaching and Research, Vol. 2, No. 5, pp. 977-988, September 2011” A Study of Factors Affecting EFL Learners' English Listening Comprehension and the Strategies for Improvement “

Krashen. S. (1980). Principles and Practice Second Language Acquisition

Kienbaum, B.E., Barrow.G.R., Russel,A.J.,\&Welty,S.1986.Communicative Competence in Foreign Language Learning with Authentic Materials. Final Project Report. (ERIC 275500)

Martinez (2000:40.41.47). Authentic Materials.

Mishan, Freda. 2005. Designing Authenticity Language Learning Materials

Miller,W.R.. (2002). Motivational Interviewing: Preparing People for Change. 2nd Edition. New York: Guilford Press.

McNeill, A. 1994. What makes Authentic Materials different? The Case of English Language Materials for Educational Television. Papers Presented at the Annual International Language in Education.

Morton, R.(1999). Abstracts as Authentic Material for EAP Classes. ELT Journal, 53(3), 177-182.

Morley. (2001:347). Authentic Texts as Cultural Mirrors: A handbook for English teachers

Nunan. (1997; 47). Theoretical and Practical Aspects of Listening Comprehension Otte. (2006 cited in Al-Musallam 2009). The Impact of Authentic Listening 
Materials on Elementary EFL Learners' Listening Skills.

Porter, D., \& Roberts, J. 1981. Authentic Listening Activities. ELT Journal, 36, $37,47$.

Ronald, Katharine, and Roskelly, Hephzibah .Listening as an act of composing. Paper Presented at the 36th Conference on College Composition and Communication. 1985. 12pp. [ED 257 094]

Mewald, R,Gasner, and Sigot,k.(2007:468). The Effect of Authentic Versus Nonauthentic Aural Materials on EFL Learners' Listening Comprehension .....Language with a Purpose: Using Authentic Materials in the Foreign Language Classroom». Foreign Language Annals 21 (1988): 467-78.

Rost, M. 2002. Teaching and Researching Listening. London, UK: Longman Salmi. 2012. Using Top down Processing Strategy in Improving Student's Listening Comprehension. Thesis. English Department Faculty of Teacher Training and Education University of Muhammadiyah Makassar.

Sabet. (2006). The Use of Authentic Materials in the Teaching of Reading. Reading Matrix vol.6, no.2

Schmitt. (2002:193). Extensive Reading and Development of Different Aspects of

\section{L2 Proficiency}

Spelleri.Maria. (2002). A Review on the Effectiveness of Using Authentic Materials in ESP Courses Zahra Zohoorian Vahid baghban Islamic Azad University of Mashhad Professor Ambigapathy, Pandian University Science Malaysia

Tamo. D. International Journal Article 9 in LCPJ “The Use of Authentic Material in Classrooms"

Thanajaro, Metinee; Shurm, J. L. 2000.Using Authentic Materials to Develop Listening Comprehension in the English as a Second Language Classroom. Virginia Polytechnic Institute and State University

Tomlinson's. (1984:5). Approaches for Teaching Empathic Listening.

Underwood, Mary 1989 Teaching listening (handbooks for language teacher) London, Oxford University Press. 